\section{Triassic Plant Remains from the Salt Range in the Punjab}

Dr. Sitholey" has described some "bivalved structures" from the Triassic of the Salt Range in the Punjab, which he says "are remarkably like the alga Cosmarium"; but he admits that "the latter is far too small to be compared with them". He then compares these structures to Arnold's Greenland organism "undergoing fission". From his description and the photographs, however, I was inclined to think that these structures could best be compared with some two-winged spores, with which they agree both as regards their size and their shape and general appearance.

With the view of confirming my doubts, I examined some of Dr. Sitholey's beautifully coloured specimens which he was kind enough to show me, and I am now convinced that this so-called "most intriguing type" should be referred to Pityosporites Seward, a spore form which was fairly common in the Lower and the Upper Gondwana floras ${ }^{2}$. Similarly, the "disc-like bodies" (Sitholey, loc. cit., p. 322, and photos 58-60) found in "fairly large numbers" are, I believe, one-winged spores with a central body and a peripheral bladdery wing forming the "thick wing" (due to the formation of a cast of the air cavity). Similar one-winged spores are one of the commonest types in the Lower Gondwana beds ${ }^{3}$. Dr. Sitholey, while mentioning that these might be "some kind of spores", adds that "there is no real proof of their organic nature"; but it might be said that the proof is as good for these as it is for the other types which have been referred by him to the spore genera $I$ riletes and Sporites.

It seems that the conditions of fossilization, at this spot, were very suitable for the formation of casts, and they have been formed even in the case of such minute structures. The occurrence of almost identical two-winged, one-winged and other spores (Triletes, Sporites, etc.) in the immediately preceding Lower Gondwana beds not only confirms the above conclusions but also might perhaps indicate some relationship between these two floras, a thing which is in accord with the views of Seward and Sahni ${ }^{4}$. The relative frequency of the various types of spores in the two floras has, however, to be determined before this can be said with any certainty.

Botany Department,

University of Allahabad. Dec. 24.

${ }^{1}$ Proc. Nat. Acad. Sci. Ind., 322 and photos 65-70 (1943).

2 Virkki, Proc. Ind. Acad. Sci. (1937); Proc. Nat. Acad. Sci. Ind. (1946). Seward, Brit. Antarctic Exp. 1910 (Nat. Hist. Rept. 1914). Thomas, Ann. Bot. (1931); Phil. Trans. Roy. Soc. (1933). Rao, Proc. Nat. Acad. Sci. Ind. (1943) and others.

s Virkki, Proc. Ind. Acad. Sci. (1939); Proc. Nat. Acad. Sci. Ind. (1946).

"Wadia, "Geology of India", 136 (1944).

\section{Formation of Citrate in vivo Induced by Fluoroacetate Poisoning}

THE intensely toxic action of the rat poison sodium fluoroacetate $\left(\mathrm{CH}_{2} \mathrm{~F}\right.$.COONa) upon the central nervous system and heart is of special interest because of the stability of the carbon - fluorine link. Bartlett and Barron ${ }^{1}$ have suggested that it competes with acetate ion in intermediary metabolism, and Saunders ${ }^{2}$ and colleagues that larger chain com- pounds of this type must be convertible to $\mathrm{CH}_{2} \mathrm{~F}$.CO to show toxicity. Recently Liébecq and Peters ${ }^{3,4}$, using centrifuged guinea pig kidney homogenates, have found that the oxidation of citrate formed from fumarate is inhibited by fluoroacetate. They have proposed the further hypothesis that this poison is metabolized like acetate and enters the tricarboxylic cycle, eventually 'jamming' this and causing accumulation of citrate.

We have now obtained further evidence for this hypothesis in vivo; rats injected with sodium fluoroacetate show relatively large accumulations of citrate in heart," kidney and brain tissue.

\begin{tabular}{|c|c|c|}
\hline & \multicolumn{2}{|c|}{ Citric acid $(\gamma) / \mathrm{gm}$. fresh tissue } \\
\hline Heart & $\begin{array}{c}\text { Normal } \\
(10) \\
0-58 \\
(8)\end{array}$ & $\begin{array}{c}\text { Poisoned } \\
(7) \\
558-810\end{array}$ \\
\hline Kidney & $0-48$ & $854-1220$ \\
\hline Brain & $\begin{array}{c}(7) \\
0-46\end{array}$ & $\begin{array}{c}(7) \\
118-271\end{array}$ \\
\hline
\end{tabular}

Figures in brackets indicate the number of animals tested. Dose Na-FAc $=5 \mathrm{mgm}$. $/ \mathrm{kgm}$. body-weight intraperitoneally ; animals killed 1 hour after the injection. The method of Pucher et al..$^{5}$ was used for citrate estimation, after boiling with acid; 'aikali heating'
did not destroy the substince estimated (see Breusch and Tulus ${ }^{\circ}$ ).

This is interesting support both for the hypothesis proposed and also for the existence of a tricarboxylic acid cycle as a metabolic path in vivo.

We are grateful to Dr. B. C. Saunders for the fluoroacetate used.

\section{Department of Biochemistry, Oxford. March 10.}

'Bartlett, G. R., and Barron, E. S. G., J. Biol. Chem., 170, 67 (1947). ${ }^{2}$ Saunders, B. C., Nature, 160, 179 (1947).

${ }^{3}$ Liébecq, C., and Peters, R. A., Proc. Physiol. Soc. (June 1948). 'Liébeca. C., and Peters, R. A., Biochim. et Biophys. Acta, 3, 215

${ }^{5}$ Pucher, G. W., et al., J. Biol. Chem., 113, 235 (1936).

'Breusih, F. L., and Tulus, R., Biochim. et Biophys. Acta, 1, 77 (1947).

\section{Influence of Aneurin and Aneurin Pyrophos- phate on Anaerobic Pyruvate Metabolism of Pig Heart Muscle in vitro}

IN the course of investigations on the anaerobic metabolism of pyruvate by minced pig heart muscle, we made some observations on effects of aneurin and aneurin pyrophosphate, which we think worth recording in this preliminary note. We will discuss only the influence of both compounds on carbon dioxide production, and postpone the description of effects observed on the formation of other metabolic products such as lactic acid, acetoin, etc.

The carbon dioxide production of Latapie-mince of the muscle of the left ventricle, suspended in phosphate buffer, $p H 6 \cdot 2$, containing manganese ions, was measured in the Warburg apparatus at $38^{\circ} \mathrm{C}$. Each vessel contained $330 \mathrm{mgm}$. of tissue; $2 \mathrm{mgm}$. sodium pyruvate was tipped in from the side-bulb. The mince was examined when fresh and also after having been stored during varying times at $+1^{\circ} \mathrm{C}$.

Without added pyruvate, the carbon dioxide production was of the order of $10 \mathrm{~mm} .^{3}$ in three or four hours; it was not influenced by adding aneurin pyrophosphate or aneurin. 